\title{
O Rio Tibagi e suas representações: a polêmica da água e o desenvolvimento do Projeto Tibagi (1970 - 2000)
}

\author{
The Tibagi river and representations: \\ a water controversy and development of Tibagi Project(1970 - \\ 2000)
}

\author{
Eliane Aparecida Biasetto*
}

\section{RESUMO}

O rio Tibagi na cidade de Londrina, durante os anos de 1970 e 1980 foi motivo de muita discussão e polêmica devido ao projeto de captação de suas águas para o abastecimento da população das cidades de Londrina e região. Em matérias publicadas em jornais, sobretudo no Jornal Folha de Londrina, nas décadas de 1970 e 1980, foi possível identificar que, neste momento, emergiu a percepção de que o rio estava poluído. Deste modo, o nosso objetivo principal na primeira parte desta pesquisa é investigar como se deu a formação desta imagem. Para tanto foi utilizado a coleção de recortes de jornais sobre a polêmica da captação das águas do Tibagi e entrevistas com o engenheiro civil Nelson Amanthea e com o engenheiro agrônomo Marcos Antonio Castanheira, ambos participaram das discussões sobre o Projeto. Foi neste período, que o ideário da era da ecologia penetrou e começou a circular na cidade no final da década de 1970. Neste contexto, o do surgimento da "era da ecologia", as denúncias e ações de combate à poluição começavam a se tornar mais efetivas e amplas, assim também, surgiram as associações ambientalistas, órgãos governamentais especializados e legislação específica. Deste modo, o também objetivo dessa pesquisa é investigar a participação de cientistas e instituições na questão ambiental, através da investigação do rio Tibagi que tornou-se evidente no final dos anos de 1980 e início da década seguinte quando a Universidade Estadual de Londrina-PR iniciou pesquisas na bacia do rio Tibagi. Destaca-se a participação dos membros do Departamento de Biologia Animal e Vegetal - UEL, a empresa Klabin Celulose e Papel, de Telêmaco Borba-PR e o COPATI- Consórcio Intermunicipal da Bacia do Tibagi, nos projetos e ações com objetivo de promover a sua recuperação. Uma das principais ações investigadas foi o Projeto "Aspecto da Fauna e Flora do Rio Tibagi" que ficou conhecido como "Projeto Tibagi". Neste sentido busquei investigar as origens do Projeto, os principais participantes envolvidos, o seu

"Mestre em História Social pelo Programa de Pós-Graduação em História Social - Universidade Estadual de Londrina - UEL, 2014. 
desenvolvimento, os resultados da pesquisa, as motivações que levaram o Projeto a ser encerrado e a relação dos cientistas com o rio. As principais fontes utilizadas foram os jornais Folha de Londrina e Notícias UEL; depoimentos de pesquisadores da UEL e relatórios do projeto Tibagi.

Palavras-chave: Londrina. Representações. Era da Ecologia. Projeto Tibagi.

\section{ABSTRACT}

The river Tibagi from the city of Londrina, in the years 1970 and 1980 was a subject of much discussion and controversy due to the project of raising its waters to supply the population of the cities of Londrina and region. In articles published in newspapers, especially in the Folha de Londrina, in the 1970s and 1980s, it was identified that, this time, the perception emerged that the river was polluted. Thus, our primary goal in the first part of this research is to investigate how it came to creating this image. Therefore, we used a collection of newspaper clippings about the controversy raised from the waters Tibagi and interviews with Nelson Amanthea civil engineer and agronomist Marcos Antonio Castanheira, both participated in discussions on the project. It was in this period that the ideas of ecology was entered and began to circulate in the city in the late 1970s. In this context, the emergence of the "age of ecology", allegations and actions to combat pollution started to become more effective and broad, as well as, arose environmental associations, specialized government agencies and specific legislation. Thus, the objective of this research is also investigating the involvement of scientists and institutions in environmental issues through research of river Tibagi that became evident in the late 1980 and early next decade when the University State of Londrina initiated research in Tibagi river basin. Is emphasized the participation of members of the Department of Animal Biology and Plant - UEL, the company Klabin Pulp and Paper, Telêmaco Borba - PR and COPATI Intermunicipal Consortium of Tibagi Basin, projects and actions in order to promote their recovery. A major action was investigated Project "Appearance of Fauna and Flora River Tibagi" which became known as "Project Tibagi ". In this sense sought to investigate the origins of the project, the main participants involved, their development, search results, the motivations that led the design to be closed and the relationship of scientists with the river. The main sources used were the newspaper Folha de Londrina and Notícias UEL; testimonials from researchers UEL and reports Tibagi Project.

Keyword: Londrina. Representations. Age of Ecology. Tibagi Project. 